\title{
Sediment-to-water fluxes of particulate material and microbes by resuspension and their contribution to the planktonic food web
}

\author{
Sam C. Wainright*
}

Department of Zoology and Institute of Ecology, University of Georgia, Athens, Georgia 30602, USA

\begin{abstract}
Resuspension of bottom sediments by waves, currents, and biota is a potentially important mechanism by which particulate materials are introduced into the water column. Fluxes of particulate materials between sediments and overlying water were determined in the laboratory. Box cores of nearshore marine sediments were subjected to defined shear stresses in an annular flume. Sediment resuspension was detectable at shear velocities $\left(u_{*}\right)$ of 0.95 to $1.35 \mathrm{~cm} \mathrm{~s}^{-1}$ in sediments ranging from fine to coarse sands. An average sediment subjected to shear velocities of 1.16 to $1.50 \mathrm{~cm} \mathrm{~s}^{-1}$ contributed 346 to $2312 \mathrm{mg}$ particulate $\mathrm{C} \mathrm{m}^{-2} \mathrm{~h}^{-1}, 43$ to $266 \mathrm{mg}$ particulate $\mathrm{N} \mathrm{m}^{-2} \mathrm{~h}^{-1}$, and $3.5 \times 10^{11}$ to $2 \times 10^{12}$ bacteria $\mathrm{m}^{-2} \mathrm{~h}^{-1}$ These fluxes would increase the concentrations of those substances in a $10 \mathrm{~m}$ homogeneouslymixed water column by 37 to $246 \mu \mathrm{g}$ particulate carbon $\mathrm{l}^{-1}, 4.6$ to $28.3 \mu \mathrm{g}$ particulate $\mathrm{N}^{-1} \mathrm{~h}^{-1}$, and $3.7 \times 10^{4}$ to $2.2 \times 10^{5}$ bacteria $\mathrm{l}^{-1} \mathrm{~h}^{-1}$, and would double typical water column concentrations in the field within a few hours. Shear stresses applied to sediments in these simulations represent mild field resuspension conditions (on the order of $0.5 \mathrm{~m}$ amplitude waves in $20 \mathrm{~m}$ water depth). Intense winter storms, which are not uncommon, would likely increase flux estimates according to the depth of sediment fluidization, and according to depth profiles of sedimentary physico-chemical parameters Resuspension, in this study area, appears to play a greater role in relocating particulate than dissolved nutrients.
\end{abstract}

\section{INTRODUCTION}

Resuspension of marine sediments represents not only a loss of material from the benthos, but a gain of material to the water column and plankton. Hopkinson (1985) stated that 'Resuspension appears to control the relative amounts of organic carbon, as well as the sites and rates of organic matter degradation in the benthos and water column: Fanning et al. (1982) concluded that resuspension may be an important provider of dissolved nitrogen compounds for phytoplankton, based on a combination of field data collected during a storm and laboratory stirring experiments. Wainright (1987) performed feeding experiments using heterotrophic microorganisms as consumers of resuspended sedimentary material, and found that planktonic microbial growth was stimulated by resuspended sediments within a few hours.

Further up the food chain, resuspended organic

- Present address: The Ecosystems Center, Marine Biological Laboratory, Woods Hole, Massachusetts 02543, USA. matter may be a source of nutrition to filter-feeding organisms (Rhoads et al. 1975, Tenore 1977, Rhoads et al. 1984). Rhoads (1973) reported that transplanting oysters from a commercial bed of coarse-grained sediments to racks suspended above a muddy bottom subject to frequent resuspension produced higher meat yields than oysters grown in the commercial beds.

It is important to know the relationship between the magnitude of the resuspension flux of organic material and the erosional shear stress required to cause that flux. There have been a number of studies to determine the critical erosion velocities of sediments, i.e. the water velocity which produces movement of sediments (e.g. Rhoads et al. 1978, Grant et al. 1982, Grant \& Gust 1987). However, data on critical resuspension velocities and the resulting material fluxes into the water column are rare. Gust \& Morris (1989) give in situ estimates of bulk sediment fluxes. Wainright $(1985,1986)$ and Ferguson et al. (1987) were the first to directly estimate the magnitude of the microbial flux from the sediment to the water column at defined shear stresses.

This paper reports the critical shear velocity for 
resuspension $\left(u_{*, c r-r}\right)$ and resuspension flux estimates for particulate $C$ and $N$, total seston, and microbes for a variety of nearshore sediments.

\section{METHODS}

Field sampling. Box cores of sediment were collected at 5 stations in the Georgia Bight off Savannah, Georgia, USA, in $20 \mathrm{~m}$ of water of less (Fig. 1). Sampling sites were chosen because of their widely varying sediment characteristics. Cores were quickly transported to the laboratory under temperature-controlled conditions. Stn OS (Offshore Sand) was sampled at each sampling period, to give a detailed picture of seasonal changes. Descriptions of sampling stations and sampling times are given in Table 1.

Sediment characteristics were determined from cores collected concurrently with those collected for flume experiments. Carbon and nitrogen analyses followed the method of Hedges \& Stern (1984). The depth of the

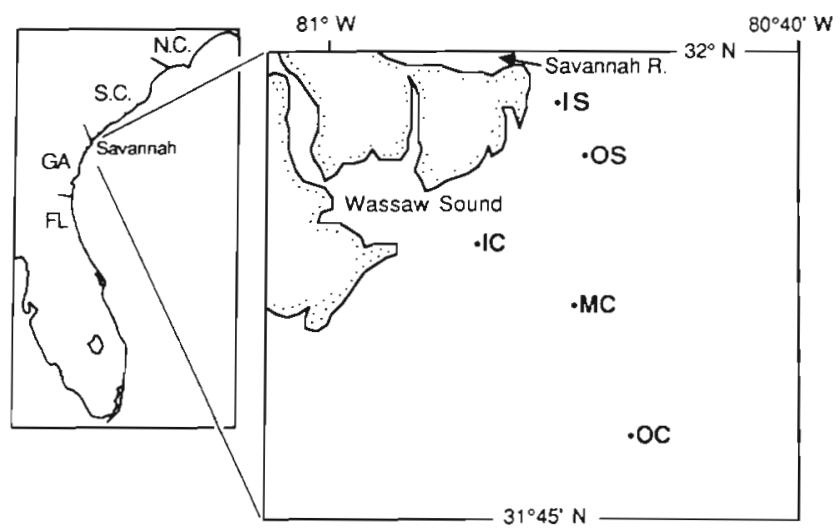

Fig. 1. The study area. Station coordinates are as follows: Inner Sand (IS), 31 $57.8^{\prime} \mathrm{N}, 80^{\circ} 50.4^{\prime} \mathrm{W}$; Outer Sand (OS), $31^{\circ}$ $56.0^{\prime} \mathrm{N}, 80^{\circ} 48.5^{\prime} \mathrm{W}$; Inner Channel (IC), 31 $53.2^{\prime} \mathrm{N}, 80^{\circ} 53.4^{\prime}$ W; Mid Channel (MC), $31^{\circ} 51.3^{\prime} \mathrm{N}, 80^{\circ} 49.7^{\prime} \mathrm{W}$; Outer Channel (OC), 31 $47.2^{\prime} \mathrm{N}, 80^{\circ} 46.6^{\prime} \mathrm{W}$

Table 1. Station descriptions and sampling periods

\begin{tabular}{|llcl|}
\hline Stn & Description & $\begin{array}{c}\text { Depth } \\
\text { (m) }\end{array}$ & Sampling periods \\
\hline OS & $\begin{array}{l}\text { Fine sand, } \\
\text { moderately sorted } \\
\text { Fine sand, } \\
\text { well sorted }\end{array}$ & 12 & $\begin{array}{l}\text { Feb, Mar, May, Jun, } \\
\text { Aug, Sep, Oct } \\
\text { Jun, Oct }\end{array}$ \\
IC & $\begin{array}{l}\text { Shell gravel, mod. } \\
\text { to well sorted } \\
\text { Medium to coarse } \\
\text { sand, mod. sorted }\end{array}$ & 12 & Aug \\
OC $\quad \begin{array}{l}\text { Coarse sand, mod. } \\
\text { to poorly sorted }\end{array}$ & 18 & Sep \\
a Based on Wentworth classification & \\
\hline
\end{tabular}

Redox Potential Discontinuity (RPD) was estimated visually as the boundary between brownish surface sediments and deeper grey-black sediments. Chlorophyll content was determined by reverse-phase HPLC using a method modified from Bidigare et al. (1985). Solvents were $79: 21(\mathrm{v} / \mathrm{v})$ methanol/water, 90:10 (v/v) methanol/water, $100 \%$ methanol, and $30: 70(\mathrm{v} / \mathrm{v})$ isopropanol/methanol, all HPLC grade (Baker). The column (Alltech Assoc.) was a $100 \times 4.6 \mathrm{~mm}$ cartridge containing Zorbax (Dupont) $7 \mu \mathrm{m}, \mathrm{C}_{18}$-bonded spherical particles. Solvents were switched isocratically at $300,550,850,1090$ s respectively, with a starting pressure of $1950 \mathrm{psi}\left(1.3 \times 10^{7} \mathrm{~Pa}\right)$. Under these conditions, chlorophyll a eluted at $860 \mathrm{~s}$, and phaeophytin a at about $1100 \mathrm{~s}$.

Resuspension experiments. An annular flume (Fukuda \& Lick 1980, P. A. Jumars \& A. R. M. Nowell pers. comm.; Fig. 2) was used to experimentally determine the thresholds of sediment resuspension, and the ensuing flux of material from the sediments to the water column. The operating principle of the annular flume is, briefly, as follows (refer to Fig. 2): The crossarm rotates, thereby rotating the ring which floats on the water in the channel. Shear stress between the ring and water induces circulation of the water in the channel. Shear velocities were determined with a flushmounted skin friction sensor, similar in principle to one

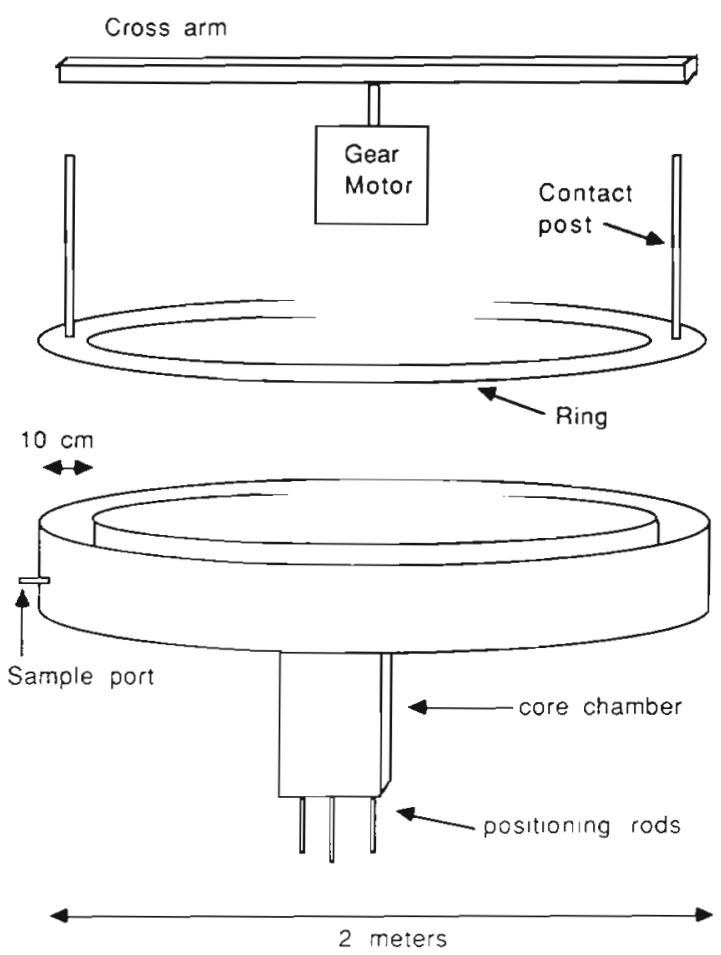

Fig. 2. Exploded view of the annular flume. The cross arm rotates, thereby rotating the ring, which floats on the water in the channel. Shear stress exerted on the water by the ring causes circulation of the water in the channel 
described in Gust (1988), but using flat, beryllium oxide-coated thermistor elements (Victory Engineering Corp., Springfield, NJ, USA). Anemometer circuitry was a modification of that described by Vogel (1981). The sensors were calibrated against similar devices in the laboratory of G. Gust (University of South Florida). Cross-channel shear velocity variation was less than $19 \%$ of the mean (Wainright unpubl.).

In this paper, shear velocity $\left(u_{\star}\right)$ will be used instead of shear stress. The 2 quantities are related as:

$$
\tau_{b}=\rho\left(u_{\star}\right)^{2}
$$

where $\rho=$ density of seawater $=1.025 \mathrm{~g} \mathrm{~cm}^{-3}$; and $\tau_{b}=$ boundary shear stress. The critical shear velocity for resuspension $\left(u_{*}, \mathrm{cr}-\mathrm{r}\right.$ ) was operationally defined as that shear velocity which produced a flux significantly different from zero $(\mathrm{p} \leq 0.05)$

The sediment-water interface for resuspension experiments was a box core of sediment that was inserted through a false bottom in the flume channel, into an acrylic chamber, to a level below that of the flume channel bottom. After insertion of the box core into the core chamber, the opening to the chamber was covered with an acrylic plate (to prevent resuspension during filling), and the flume channel filled with filtered $(0.2 \mu \mathrm{m})$ seawater to a depth of $6 \mathrm{~cm}(60 \mathrm{l})$. Filling time was generally $1.25 \mathrm{~h}$. The plate was then removed, and the core positioned flush with the flume channel bottom by means of positioning rods in the bottom of the core chamber.

Water flow was then started at a low shear velocity $\left(u_{*}=0.1 \mathrm{~cm} \mathrm{~s}^{-1}\right)$. Following an equilibration period of 20 min, a sample of water was withdrawn through a port in the sidewall of the flume for determination of initial concentrations of particulate matter and microorganisms; this sample contained concentrations present in the filtered water plus those introduced by the small amount of water overlying the sediment core, and served as a blank. Sediment was resuspended by increasing the shear velocity in a stepwise manner After each increase, the shear velocity was maintained for an equilibration period of $20 \mathrm{~min}$ and water samples withdrawn. This procedure was repeated until sediment was eroded enough to create serious artificial roughness elements (gullies).

Water column samples were collected for total suspended material (seston), particulate organic carbon (POC), particulate nitrogen (PN), and microorganisms. Bacteria/particle samples were fixed with acid-Lugol iodine solution (Nishino 1986) and refrigerated. Bacterial and particle counts followed Nishino's (1986) protocol for cellulose nitrate filters. Counts were made as follows: (1) Bacteria fell into 2 classes: $0.2 \mu \mathrm{m}$ diam. cocci, and $0.6 \times 1.0 \mu \mathrm{m}$ rods, and were counted separately. (2) Flagellated protozoans were enumerated at either $125 \times$ or $500 \times$ magnifications, depending on cell size and abundance. (3) Particles were measured individually with an occular micrometer, with the number of attached bacteria on each recorded. At least 50 particles, or the particles in 50 fields, were examined from each sample. Attached bacterial counts were multiplied by a factor of 2 to account for the reverse sides of particles (Kirchman 1983). Microbial volumes were calculated assuming cocci and spherical flagellates to be spherical, rods and ellipsoid protozoans to be ellipsoid. Average bacterial cell volumes were computed as weighted averages, based on the fraction of the total in each size class. Seston/CHN samples were collected at only 2 or 3 shear velocities in any given experiment because the relatively large volumes of water required for these analyses (several liters) dictated that few samples could be withdrawn before flow conditions were affected. Samples were filtered through precombusted, tared glass fibei filters (Reeve Angel 984H). After reweighing them, the filters were acidified, dessicated, reweighed, and subjected to $\mathrm{CHN}$ analysis (Wainright 1987).

Fluxes of materials from sediment to water column were calculated according to the relationship:

$$
\text { Flux }=\left(C_{f}-C_{i}\right) V^{-1} A^{-1}
$$

where $\mathrm{C}_{\mathrm{f}}$ and $\mathrm{C}_{1}=$ initial and final concentrations of the substance in the flume; $\mathrm{T}=$ time of exposure to a given shear velocity $\left(u_{\star}\right) ; \mathrm{V}=$ volume of the flume; and $\mathrm{A}=$ surface area of the sediment core. (Note that fluxes at a particular shear velocity do not include material which had already been eroded at lower shear velocities, i.e. they are not cumulative.) Eroded sediment travels as bedload and suspended load. The latter was determined by weighing sediment which accumulated on the flume channel floor after a flume experiment. The percentage of the sedimentary material which was resuspendable was estimated as the amount of seston (the product of concentration and volume) compared to the total amount of sediment eroded.

\section{RESULTS}

\section{Sedimentary characteristics}

Brief descriptions of the study sites are given in Table 1. Sediments from the Inner Channel station (IC) were coarsest, a large fraction of the material being intact shells or large shell fragments. Stns IS and OS contained the finest sediments and were outwardly similar, both having approximately the same texture, but differing in several important respects. Stn OS had the highest organic $\mathrm{C}$ and $\mathrm{N}$ content of all stations (Table 2), while Stn IS had among the lowest. The 
Table 2. Sedimentary characteristics at 5 sampling stations in the top $1 \mathrm{~cm}$. Inorganic carbon (IC), total organic carbon (TOC), and particulate nitrogen (PN) are expressed as percent by dry weight. $C: N$ is the ratio of carbon to nitrogen by atoms. Chl a is expressed as $\mu \mathrm{g} \mathrm{g}^{-1}$ dry wt. RPD is the depth of the Redox Potential Discontinuity. For stations sampled more than once, values are averages over all sampling periods. Means and standard errors (in parentheses) are based on numbers of replicates noted below

\begin{tabular}{|c|c|c|c|c|c|c|}
\hline Stn & $\% \mathrm{IC}^{\mathrm{a}}$ & $\%$ TOC $^{d}$ & $\% \mathrm{PN}^{\mathrm{a}}$ & $C: N$ & $\mathrm{Chl} \mathrm{a}^{\mathrm{b}}$ & $\operatorname{RPD}(\mathrm{cm})$ \\
\hline $\mathrm{OS}^{c}$ & $\begin{array}{c}0.58 \\
(0.02)\end{array}$ & $\begin{array}{l}0.15 \\
(0.005)\end{array}$ & $\begin{array}{c}0.02 \\
(0.001)\end{array}$ & $\begin{array}{c}9.30 \\
(0.67)\end{array}$ & $\begin{array}{c}1.21 \\
(0.3)\end{array}$ & $0.5-5$ \\
\hline$I^{d}$ & $\begin{array}{c}0.135 \\
(0.005)\end{array}$ & $\begin{array}{c}0.066 \\
(0.002)\end{array}$ & $\begin{array}{c}0.01 \\
(0.001)\end{array}$ & $\begin{array}{c}7.95 \\
(0.71)\end{array}$ & $\begin{array}{c}0.74 \\
(0.14)\end{array}$ & $>5-12$ \\
\hline $\mathrm{IC}^{e}$ & $\begin{array}{l}1.38 \\
(0.282)\end{array}$ & $\begin{array}{c}0.109 \\
(0.010)\end{array}$ & $\begin{array}{c}0.018 \\
(0.002)\end{array}$ & $\begin{array}{c}7.18 \\
(0.40)\end{array}$ & $\begin{array}{c}0.71 \\
(0.11)\end{array}$ & $>8$ \\
\hline $\mathrm{MC}^{\mathrm{e}}$ & $\begin{array}{c}0.18 \\
(0.024)\end{array}$ & $\begin{array}{c}0.032 \\
(0.002)\end{array}$ & $\begin{array}{c}0.008 \\
(0.001)\end{array}$ & $\begin{array}{c}5.12 \\
(0.40)\end{array}$ & $\begin{array}{c}1.34 \\
(0.18)\end{array}$ & $>8$ \\
\hline$O C^{e}$ & $\begin{array}{c}0.906 \\
(0.065)\end{array}$ & $\begin{array}{c}0.127 \\
(0.007)\end{array}$ & $\begin{array}{c}0.015 \\
(0.002)\end{array}$ & $\begin{array}{c}9.88 \\
(0.97)\end{array}$ & $\begin{array}{c}5.22 \\
(0.45)\end{array}$ & $2-3$ \\
\hline \multicolumn{7}{|c|}{ 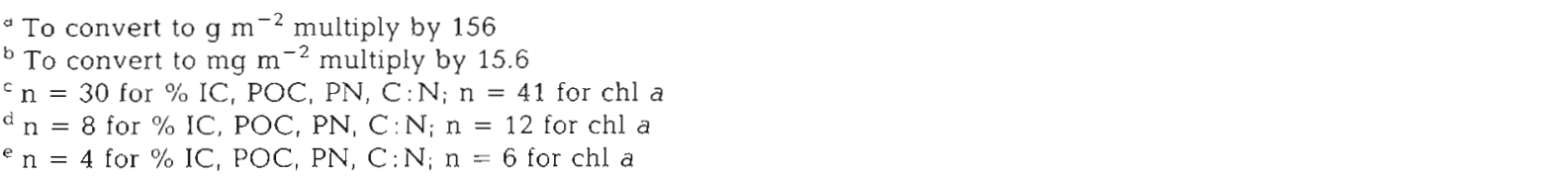 } \\
\hline
\end{tabular}

Middle Channel station (MC) and Stn IS had the lowest inorganic carbon contents. The Outer Channel station (OC) was a poorly-sorted mixture including shell fragments of all sizes. There was no consistent relationship between grain size and organic content. Sediments contained between 0.1 and $1.4 \%$ inorganic carbon $\left(1.1\right.$ to $\left.11.5 \% \quad \mathrm{CaCO}_{3}\right)$, mostly derived from bivalve shells.

The depth of the RPD varied between stations and seasonally. At Stn OS, the RPD was shallowest ( 0.5 to $1.5 \mathrm{~cm}$ ) in July and deepest $(2$ to $5 \mathrm{~cm})$ in February.

Sediment chlorophyll a concentrations were highest at Stn OC in September (Table 2). There was no significant correlation between particulate nitrogen ( $\mathrm{PN}$ ) or particulate organic carbon (POC) and chlorophyll a $(p \geqslant 0.05)$ [although chlorophyll content was weakly correlated with the $C: N$ ratio $(p=0.078)]$.

The atomic $C: N$ ratio of the sediments did not consistently vary with depth down to $5 \mathrm{~cm}(\mathrm{p}=0.57)$, but it did vary seasonally ( $p=0.0002)$, with highest ratios in October and lowest in August (2-way ANOVA). The C:N ratio of sediment approached that of phytoplankton (ca 5) in August (Stn MC), while the highest ratios (12.6 \pm 2.7 ) occurred in February (Stn OS, 4 to $5 \mathrm{~cm}$ fraction), suggesting a more refractory pool of organic material.

\section{Resuspension fluxes}

Sediment-to-water fluxes of all materials showed similar patterns, i.e. measurable fluxes at $u_{\star}=0.95$ to $1.16 \mathrm{~cm} \mathrm{~s}^{-1}$ and much greater fluxes at higher shear velocities (Fig. 3). (The shear velocity reported in Wain- right $(1987), u_{*}=1.8 \mathrm{~cm} \mathrm{~s}^{-1}$, was an overestimate. Experimental conditions were similar to the $u_{\star}=$ $1.16 \mathrm{~cm} \mathrm{~s}^{-1}$ reported here. Heated-thermistor velocity profiles, which were used to make the former
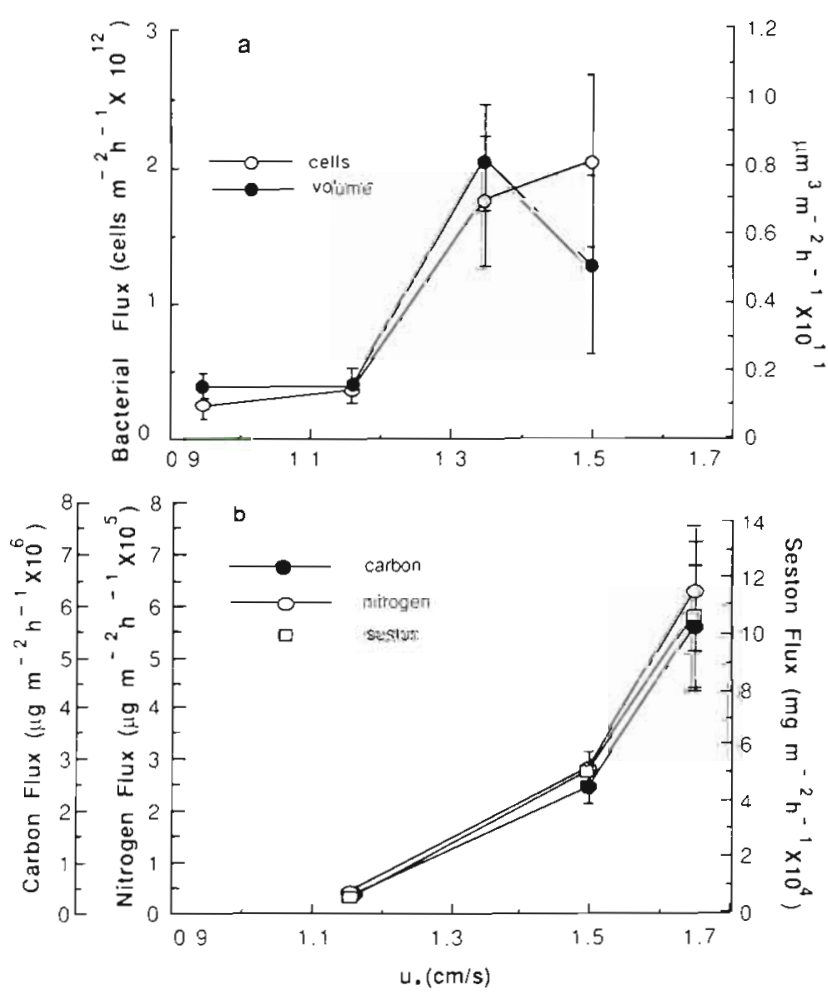

Fig. 3. (a) Bacterial fluxes from flume experiments, expressed on a numeric and on a volume basis. (b) Total seston, carbon and nitrogen fluxes from flume experiments. In all cases, plotted values are means of all runs combined; error bars are \pm 1 standard error of the mean $(n=41)$ 
estimates, are inferior to the shear stress sensors for this particular application.) $u_{\star, c r-r}$, the shear velocity which produced a significant flux of sedimentary material into the flume water, was determined to be $0.95 \mathrm{~cm} \mathrm{~s}^{-1}$ when data from all stations were combined (Fig. 3). This flux of $2.3 \times 10^{11} \pm 7.7 \times 10^{10}$ cells $\mathrm{m}^{-2} \mathrm{~h}^{-1}$ is equivalent to an increase in the bacterial concentration in a homogeneously mixed $10 \mathrm{~m}$ water column of $2.4 \times$ $10^{4} \pm 8.2 \times 10^{3}$ cells $\mathrm{ml}^{-1} \mathrm{~h}^{-1}$. Estimates of increased cell concentration in $10 \mathrm{~m}$ of water may be obtained by dividing cells $\mathrm{m}^{-2} \mathrm{~h}^{-1}$ by $9.4 \times 10^{6}$. The corresponding conversion factor for seston, $\mathrm{C}$ and $\mathrm{N}$ is $9.4 \times 10^{3}$. During any particular sampling period $u_{\text {*cr-r }}$ was between 1.16 and $1.35 \mathrm{~cm} \mathrm{~s}^{-1}$. Insignificant fluxes at lower shear velocities were caused by high intrastation variability, making flux estimates insignificantly different from zero.

There were few detectable between-station, or seasonal differences regarding any flux parameter. An exception was particulate nitrogen at $u_{\star}=1.5 \mathrm{~cm} \mathrm{~s}^{-1}$,

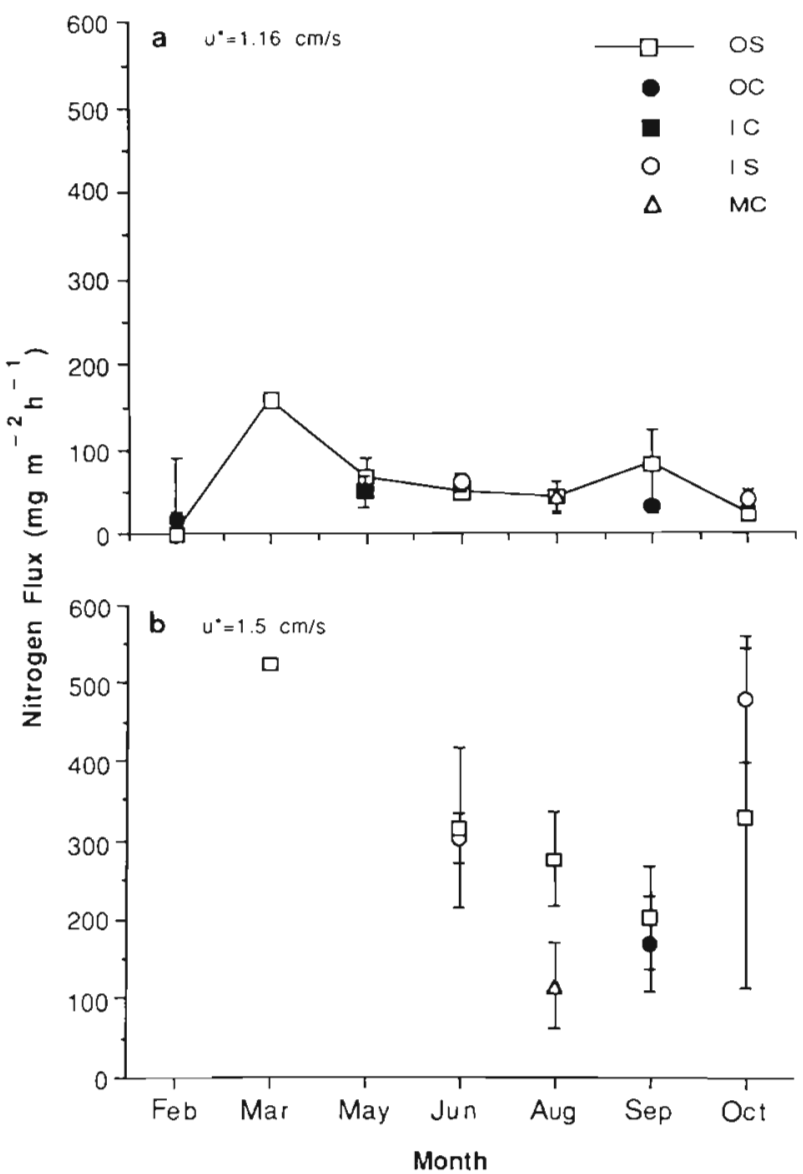

Fig. 4. Seasonal fluxes of particulate nitrogen at 2 shear velocities: (a) $1.16 \mathrm{~cm} \mathrm{~s}^{-1}$; and (b) $1.5 \mathrm{~cm} \mathrm{~s}^{-1}$. Values are means \pm 1 standard error of the mean. The plotted value of OS (Mar) is a single value, with no corresponding standard error Error bar for $\operatorname{Stn} O C$ (Feb) at $u_{*}=1.16 \mathrm{~cm} \mathrm{~s}^{-1}$ actually extends below zero. No samples were collected during Apr, where Stn OS (March) and Stn IS (October) showed significantly greater $\mathrm{N}$ fluxes than Stns MC and OC in August and September, respectively (2-way ANOVA, $p<0.05$; Fig. 4). Stn IS had a low nitrogen content (Table 2), and so its relatively large $\mathrm{N}$ flux must have been a result of unusually high erodibility, and thus high total seston flux. Although total seston flux at this station was higher than at several other stations, the difference was not significant $(p=0.07$; 2 -way ANOVA). Bacterial fluxes were significantly higher at Stn OS (February) at $u_{\star}=0.95$ and $1.16 \mathrm{~cm} \mathrm{~s}^{-1}$ (Fig. 5), suggesting that this station was more prone to erosion than average.

Bacterial fluxes from the sediments were highly correlated with the all other resuspension parameters ( $p<0.003$ or better; Table 3 ). The weakest correlation was between bacterial and particle abundances.

Samples were collected after 2 exposure times at 2 different shear velocities, to assess whether fluxes remained constant over a more extended period of

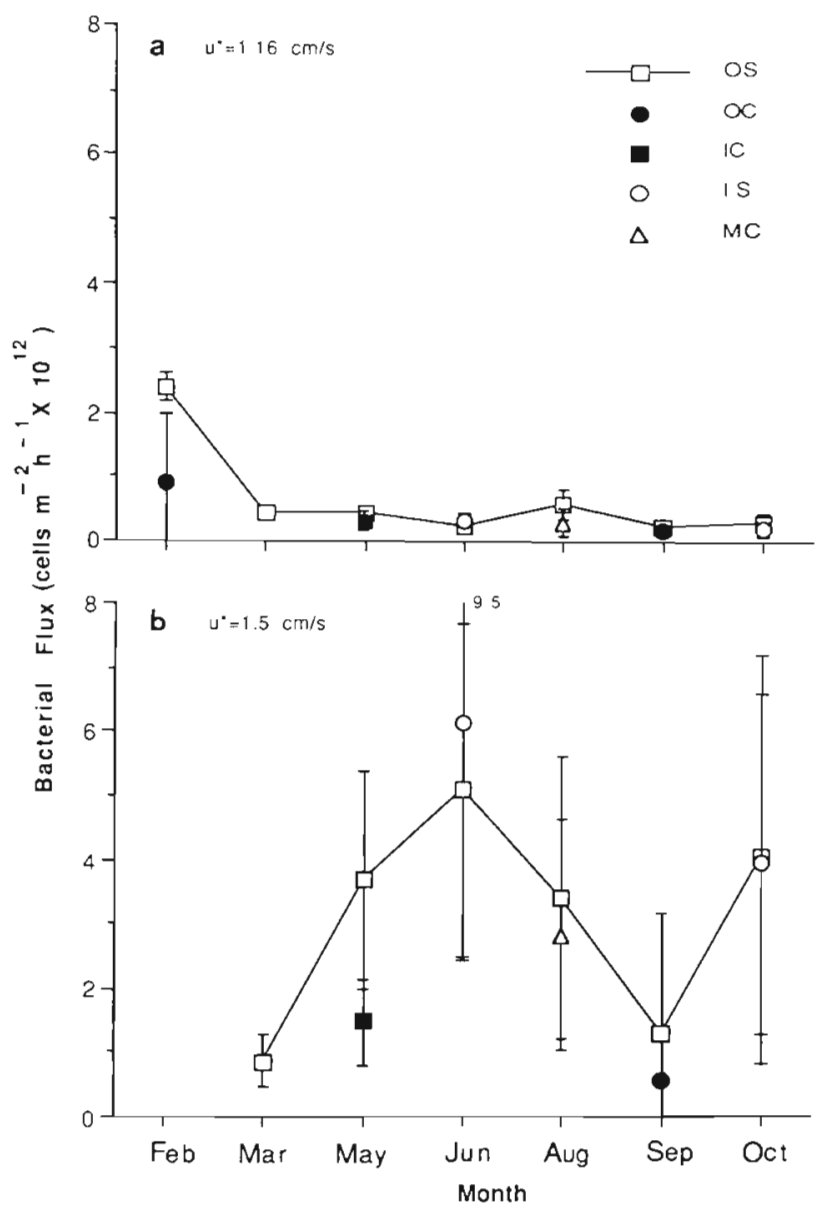

Fig. 5. Seasonal fluxes of bacteria at 2 shear velocities: (a) $1.16 \mathrm{~cm} \mathrm{~s}^{-1}$; and (b) $1.5 \mathrm{~cm} \mathrm{~s}^{-1}$ Values are means \pm 1 standard error of the mean. Error bar for Stn $O C$ (Feb) at $u_{*}=1.16$ $\mathrm{cm} \mathrm{s}^{-1}$ actually extends off scale, as do those for Stns OS (Sep) and IS (Jun) at $u .=1.5 \mathrm{~cm} \mathrm{~s}^{-1}$. No samples were collected during Apr, Jul 
time. Fluxes of bacteria and particulate material collected after $12 \mathrm{~min}$ were not significantly different from those collected at $24 \mathrm{~min}$ at $\mathrm{u}_{*}=1.16$ or $1.5 \mathrm{~cm} \mathrm{~s}^{-1}$. Thus fluxes remained constant for at least $24 \mathrm{~min}$.

\section{Characteristics of resuspended material}

Sedimentary material was 0.16 to $1.61 \%$ resuspendable on a dry weight basis (Table 4). Between 0.5 and
$2.5 \%$ of the resuspendable material was $\mathrm{PN}$, while 4.3 to $16.5 \%$ was POC, yielding atomic $\mathrm{C}: \mathrm{N}$ ratios of 7 to 23. Resuspendable material at Stn OS generally had the lowest $C: N$ ratio, while that from Stn IS (June) had the highest $C$ and $N$ contents. Lowest $C$ and $N$ contents were generally found at Stns IC and MC.

The percentage of bacteria that were attached to particles increased with shear velocity (Fig. 6a). Up to $80 \%$ of the resuspended bacteria were attached to particles (Stn N, October), however, on average about

Table 3. Correlation matrix, with Pearson correlation coefficients between flux parameters. Significance is indicated as follows: $\cdots p<0.001 ; \cdots 0.001<p<0.01$

\begin{tabular}{|c|c|c|c|c|c|}
\hline Flux & Seston & $\mathrm{N}$ & $\mathrm{C}$ & Bacteria & Particles \\
\hline Seston & 1.000 & & & & \\
\hline $\mathrm{N}$ & $0.943^{\cdots}$ & 1.000 & & & \\
\hline C & $0.967^{\cdots} \cdots$ & $0.955^{\cdots}$ & 1.000 & & \\
\hline Bacteria & $0.630^{\cdots} \cdots$ & $0.541^{\cdots} \cdots$ & $0.543^{\cdots} \cdots$ & 1.000 & \\
\hline Particles & $0.588 \cdots$ & $0.589^{\cdots} \cdots$ & $0.556^{\cdots}$ & $0.234^{\cdots}$ & 1.000 \\
\hline
\end{tabular}

Table 4. Percent of eroded material resuspended, and its composition. Percent resuspended is based on the seston concentrations in flume water relative to sediment disappearance from the experimental box cores. Percent $N, C$ and atomic $C: N$ ratios are on a dry weight basis. nd: not determined. Numbers in parentheses are standard errors

\begin{tabular}{|c|c|c|c|c|c|c|}
\hline Stn, & Month & $\mathrm{u}_{*}$ & $\%$ resusp & $\% N$ & $\% \mathrm{C}$ & $C: N$ \\
\hline \multirow[t]{7}{*}{ OS } & Feb & 1.16 & nd & $0.91 \quad(0.23)$ & $6.69(1.27)$ & $9.21(1.47)$ \\
\hline & Mar & $\begin{array}{l}1.16 \\
1.50 \\
1.65\end{array}$ & nd & $\begin{array}{ll}1.49 & (0.40) \\
1.70 & \\
0.77 & (0.08)\end{array}$ & $\begin{aligned} 7.69 & (1.42) \\
10.31 & \\
5.97 & (0.37)\end{aligned}$ & $\begin{array}{l}7.36(1.18) \\
7.09 \\
9.29(0.68)\end{array}$ \\
\hline & May & $\begin{array}{l}1.16 \\
1.65\end{array}$ & 1.61 & $\begin{array}{ll}1.50 & (0.56) \\
0.79 & (0.17)\end{array}$ & $\begin{array}{r}11.26(3.54) \\
6.50(0.78)\end{array}$ & $\begin{array}{rr}9.89 & (1.18) \\
10.61 & (1.09)\end{array}$ \\
\hline & Jun & $\begin{array}{l}1.16 \\
1.50 \\
1.65\end{array}$ & nd & $\begin{array}{ll}1.16 & (0.24) \\
0.58 & (0.06) \\
0.58 & (0.03)\end{array}$ & $\begin{array}{ll}9.48 & (1.98) \\
5.02 & (0.57) \\
4.78 & (0.36)\end{array}$ & $\begin{aligned} 9.89 & (1.14) \\
10.21 & (0.81) \\
9.53 & (0.16)\end{aligned}$ \\
\hline & Aug & $\begin{array}{l}1.16 \\
1.50\end{array}$ & 1.47 & $\begin{array}{ll}0.77 & (0.13) \\
0.67 & (0.05)\end{array}$ & $\begin{array}{ll}6.93 & (1.00) \\
5.18 & (0.32)\end{array}$ & $\begin{array}{rr}12.28 & (3.00) \\
9.12 & (0.46)\end{array}$ \\
\hline & Sep & $\begin{array}{l}1.16 \\
1.50\end{array}$ & 0.67 & $\begin{array}{ll}1.65 & (0.57) \\
0.74 & (0.09)\end{array}$ & $\begin{array}{rr}10.11 & (2.35) \\
5.97 & (0.50)\end{array}$ & $\begin{array}{ll}8.13 & (0.85) \\
9.56 & (0.42)\end{array}$ \\
\hline & Oct & $\begin{array}{l}1.16 \\
1.50\end{array}$ & 0.66 & $\begin{array}{ll}0.65 & (0.50) \\
0.64 & (0.10)\end{array}$ & $\begin{array}{l}7.82(1.63) \\
5.82(0.76)\end{array}$ & $\begin{array}{ll}16.01 & (3.42) \\
10.70 & (0.36)\end{array}$ \\
\hline \multirow[t]{2}{*}{ IS, } & Jun & $\begin{array}{l}1.16 \\
1.50\end{array}$ & nd & $\begin{array}{l}2.48(0.98) \\
1.01(0.42)\end{array}$ & $\begin{array}{r}16.49 \\
7.23(1.89) \\
(1.34)\end{array}$ & $\begin{array}{r}9.25(1.51) \\
11.49(2.05)\end{array}$ \\
\hline & Oct & $\begin{array}{l}1.16 \\
1.50\end{array}$ & 0.16 & $\begin{array}{l}0.84(0.11) \\
0.50(0.02)\end{array}$ & $\begin{array}{ll}7.66 & (1.02\} \\
4.46 & (0.26)\end{array}$ & $\begin{array}{ll}10.73 & (0.57) \\
10.44 & (0.71)\end{array}$ \\
\hline OC, & Feb & 1.16 & nd & $0.74(0.08)$ & $7.11 \quad(0.24)$ & $11.70(0.91)$ \\
\hline & Sep & $\begin{array}{l}1.16 \\
1.50\end{array}$ & 0.36 & $\begin{array}{ll}0.78 & (0.17) \\
0.92 & (0.16)\end{array}$ & $\begin{array}{l}7.40(1.37) \\
7.69(1.24)\end{array}$ & $\begin{array}{r}13.34(3.91) \\
9.84 \quad(0.34)\end{array}$ \\
\hline $\mathrm{IC}$ & May & $\begin{array}{l}1.16 \\
1.35 \\
1.65\end{array}$ & 1.33 & $\begin{array}{ll}0.55 & (0.13) \\
0.60 & (0.06) \\
0.62 & (0.04)\end{array}$ & $\begin{array}{ll}8.40 & (0.99) \\
7.12 & (1.23) \\
5.58 & (0.12)\end{array}$ & 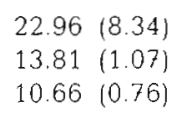 \\
\hline$M C$ & Aug & $\begin{array}{l}1.16 \\
1.50\end{array}$ & 0.29 & $\begin{array}{ll}0.64 & (0.21) \\
0.47 & (0.06)\end{array}$ & $\begin{array}{ll}5.62 & (1.64) \\
4.29 & (0.34)\end{array}$ & $\begin{aligned} 9.24 & (0.55) \\
10.94 & (0.64)\end{aligned}$ \\
\hline
\end{tabular}



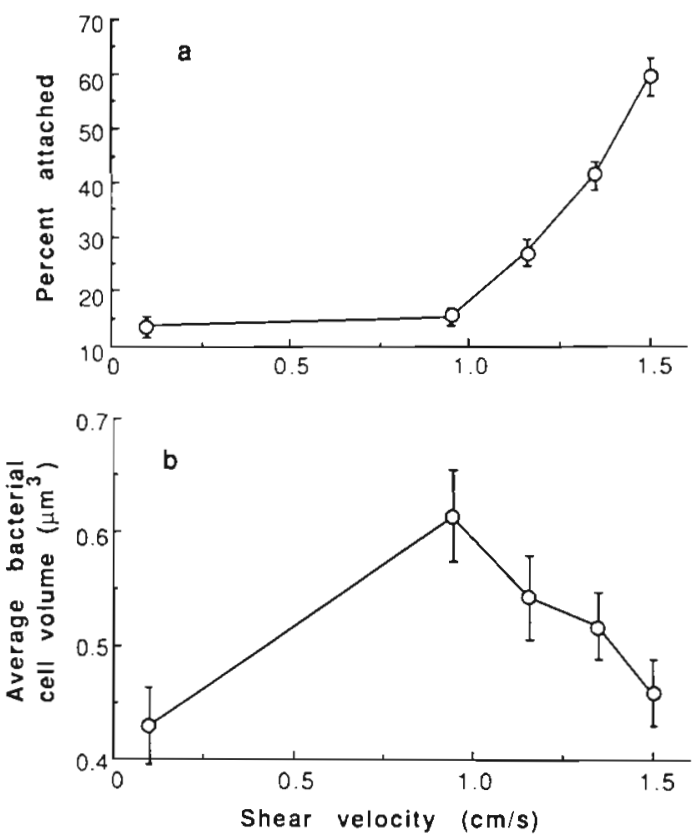

Fig. 6. (a) Percentage of resuspended bacteria attached to particles. Plotted values are means of all runs combined ( $\mathrm{n}=$ 41) \pm 1 standard error of the mean. (b) Average bacterial cell volumes of resuspended bacteria in flume experiments. Plotted values are means of all runs combined $(n=41) \pm 1$ standard error of the mean

$60 \%$ of resuspended bacteria were attached to particles at the highest $u_{\text {* examined. }}$

Average bacterial cell volume (Fig, 6b) was typically maximum at or before the point where there was significant resuspension. Bacterial fluxes appeared to increase between $u_{\star}=1.35$ and $1.5 \mathrm{~cm} \mathrm{~s}^{-1}$ when viewed numerically, but decreased on a volume basis (Fig. 3). However, in both cases, fluxes at $u_{\star}=0.95$ and $1.16 \mathrm{~cm} \mathrm{~s}^{-1}$ were statistically indistinguishable from each other, as were those at $u_{*}=1.35$ and $1.5 \mathrm{~cm} \mathrm{~s}^{-1}$.

Flagellated protozoa (mostly 4 to $5 \mu \mathrm{m}$ diameter)

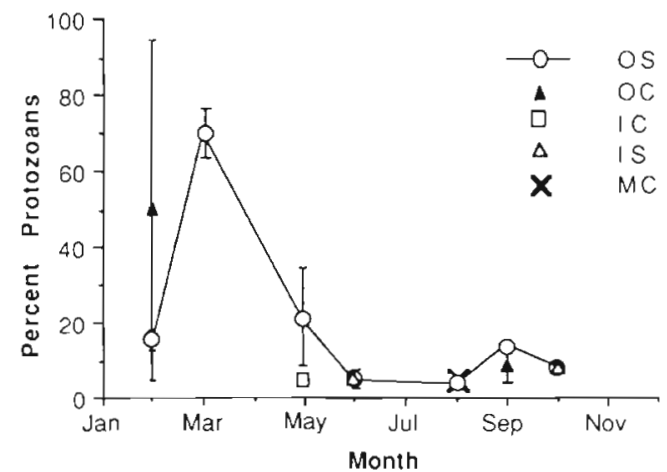

Fig. 7 Percentage of total microbial fluxes attributable to protozoans, on a volume basis. Plotted values are means and standard errors of fluxes from 2 to 4 cores per sampling period; each core's flux was itself a mean of fluxes from 4 shear velocities were a significant component of the microbial biomass. These organisms were most numerous during February and March (Fig. 7), comprising 14 to $98 \%$ of microbial biovolume at both Stns OC and OS. However, protozoan volume was typically less than $10 \%$ of total microbial biovolume in all other resuspended microbial communities. Diatoms were infrequently observed, but in insufficient numbers to quantify.

\section{DISCUSSION}

\section{Contribution of resuspended materials to the plankton}

Resuspended sedimentary material may contribute very significantly to normal water column concentrations of all substances examined (Table 5). Using water concentrations of materials from the study area for comparison, estimates were made of the contribution of resuspended material to the average field concentrations of these substances. Measured laboratory fluxes could double typical planktonic field concentrations within an hour at $u_{\star}=1.5 \mathrm{~cm} \mathrm{~s}^{-1}$ or a few hours at $u_{*}=1.16 \mathrm{~cm} \mathrm{~s}^{-1}$. While it was not possible to demonstrate a significant time-dependent reduction in the magnitude of resuspension fluxes on the order of 24 min, Fanning et al. (1982) found the greatest release of dissolved nutrients in the initial few minutes of their 'stirring experiment', despite the relatively small amount of sediment eroded. It is likely that this also applies to suspendable particulate nutrients, the implication being that once fluidized, sediments yield a diminishing return as resuspension persists.

Interestingly, attached bacteria comprised the bulk of the bacterial flux (Fig. 6a). While it is commonly thought that most planktonic bacteria are free-living, there are a number of reports of high proportions of attached bacteria in relatively turbid waters, in terms of both numbers and activity (e.g. Bell \& Albright 1981, Schoenberg \& McCubbin 1985, Plummer et al. 1987). Plummer et al. (1987) concluded that bacteria attached to resuspended particles were relatively unimportant compared with those attached to permanently suspended particles in estuaries, while Palumbo et al. (1984) stated that resuspension was an important determinant of the number of attached bacteria in the Georgia Bight.

The relationship between bacterial cell volume and shear velocity suggests a relationship between cell size and sediment depth. Bacteria resuspended first were larger than those resuspended later. Deeper sediment bacteria, which appeared in the water column only at greater shear velocities, had smaller average cell size. Reasons for smaller bacteria at depth may include the 
Table 5. Comparison of increased seston, nitrogen, carbon and bacterial concentrations due to resuspension at 2 shear velocities with typical concentrations of those substances in the study area and surrounding area. Flume fluxes were converted to increased concentrations in a $10 \mathrm{~m}$ water column per hour, using box core surface area and flume volume, and assuming homogeneous mixing. For increased concentrations, units are $\mathrm{mg} \mathrm{l}^{-1} \mathrm{~h}^{-1}$ for seston, $\mu \mathrm{gl}^{-1} \mathrm{~h}^{-1}$ for PN, POC, and cells $\mathrm{ml}^{-1} \mathrm{~h}^{-1}$ for bacteria

\begin{tabular}{|c|c|c|c|c|}
\hline Substance & $\begin{array}{l}\text { Typical field } \\
\text { concentrations }\end{array}$ & Source & $\begin{array}{l}\text { Range of incre } \\
\text { at } \mathrm{u}_{*}=1.16 \mathrm{~cm} \mathrm{~s}\end{array}$ & $\begin{array}{l}\text { concentrations } \\
\text { at } \mathrm{u}_{*}=1.5 \mathrm{~cm} \mathrm{~s}^{-1}\end{array}$ \\
\hline Seston & $\begin{array}{l}5-200 \mathrm{mg} \mathrm{l}^{-1} \\
2-15\end{array}$ & $\begin{array}{l}\text { Oertel \& Dunstan (1981) } \\
\text { Wainright (unpubl.) }\end{array}$ & $0.1-0.9$ & $1.8-10.1$ \\
\hline PN & $\begin{array}{l}2-76 \mu \mathrm{g} \mathrm{I}^{-1} \\
16-110\end{array}$ & $\begin{array}{l}\text { Haines \& Dunstan (1975) } \\
\text { Wainright (unpubl.) }\end{array}$ & $0-15.9$ & $11-52.4$ \\
\hline POC & $\begin{array}{l}35-800 \mu \mathrm{g} \mathrm{I} I^{-1} \\
150-900\end{array}$ & $\begin{array}{l}\text { Haines \& Dunstan (1975) } \\
\text { Wainright (unpubl.) }\end{array}$ & $0-70.4$ & $107-433$ \\
\hline Bacteria & $10^{5}-10^{6}$ cells $\mathrm{ml}^{-1}$ & $\begin{array}{l}\text { Wainright (unpubl.) } \\
\text { Pomeroy (1985) }\end{array}$ & $0.1-2.4 \times 10^{5}$ & $0.5-5 \times 10^{5}$ \\
\hline
\end{tabular}

refractory nature of buried organic matter (although this was not evident in the $\mathrm{C}: \mathrm{N}$ ratios), diffusionlimited uptake of oxygen and nutrients in subsurface sediments and reduced bacterial grazing in surface sediments.

\section{Storm estimates}

Shear velocities used in this study $\left(0\right.$ to $\left.1.5 \mathrm{~cm} \mathrm{~s}^{-1}\right)$, while exceeding $u_{\star, c r-r}$, were probably far lower than maximal shear velocities experienced in the study area during storms. A wave-current interaction model (Grant \& Madsen 1979) was used to calculate shear velocities, using current and wave information as input. Shear velocities ranged from 1.5 to $6 \mathrm{~cm} \mathrm{~s}^{-1}$ (Table 6; T. F. Gross, Skidaway Institute of Oceanography, pers. comm.). Shallow areas are especially prone to resuspension (compare $4 \mathrm{~m}$ with $18 \mathrm{~m}$ run). Wiberg \& Smith (1983) reported shear velocities as 4.5 to $5.2 \mathrm{~cm} \mathrm{~s}^{-1}$ during a storm at an $18 \mathrm{~m}$ station off Alaska. Other

Table 6. Expected shear velocities in the study area, computed using the Grant \& Madsen (1979) wave-current interaction model. Default conditions are: $z=12 \mathrm{~m}$, roughness length $\left(\mathrm{K}_{\mathrm{b}}\right)$ $=0.3 \mathrm{~cm}$, current velocity $1 \mathrm{~m}$ off bottom $=20 \mathrm{~cm} \mathrm{~s}^{-1}$, wave angle to current axis $=0^{\circ}$, wave period $=5 \mathrm{~s}$, wave height $(1 / 2$ peak to (rough) $=50 \mathrm{~cm}$. In a given combination, only the indicated parameter has been changed from the default value

\begin{tabular}{|lc|}
\hline Changed parameter & $\begin{array}{c}\text { Resulting shear velocity } \\
\left(\mathrm{cm} \mathrm{s}^{-1}\right)\end{array}$ \\
\hline None; all default values & 2.44 \\
$z=4 \mathrm{~m}$ & 5.95 \\
$z=18 \mathrm{~m}$ & 1.50 \\
$\mathrm{~K}_{\mathrm{b}}=3 \mathrm{~cm}$ & 3.98 \\
Current velocity $=2 \mathrm{~cm} \mathrm{~s}^{-1}$ & 2.04 \\
Wave angle $=90^{\circ}$ & 2.09 \\
Wave period $=10 \mathrm{~s}$ & 3.76 \\
Wave height $=150 \mathrm{~cm}$ & 5.23 \\
\hline
\end{tabular}

factors such as bottom roughness, wave height and wave period also have large effects on $u_{\star}$. In the context of particle movement, $u_{\star}$ produced by steady unidirectional flow (as in the flume experiments) is equivalent to that produced by waves or wave-current interaction (Nowell \& Jumars 1984); that is, particles would not distinguish between $\mathrm{u}_{\star}=2 \mathrm{~cm} \mathrm{~s}^{-1}$ produced by waves and $u_{\star}=2 \mathrm{~cm} \mathrm{~s}^{-1}$ produced by currents.

Storm events show enormous potential for shifting pools of particulate organic matter from the benthos to the plankton. Hopkinson (1987) observed sediment fluidization down to $25 \mathrm{~cm}$. While it is unknown exactly what values of $u_{*}$ might produce sediment fluidization down to $25 \mathrm{~cm}$, it is interesting to extrapolate my estimates of ' $\%$ suspendable' to volumes of fluidized sediment reported by Hopkinson (1987). Assuming that fluidization releases all resuspendable material down to that depth, using a conservative value of $0.16 \%$ resuspendable (Table 4 ), and a sediment bulk density of $1.5 \mathrm{~g} \mathrm{~cm}^{-3}, 600 \mathrm{~g}$ of material would be resuspended per $\mathrm{m}^{2}$. This is probably an underestimate, since the $u$ * capable of this sort of erosion would likely have a higher '\% resuspendable' value associated with it. Multiplying the dry weight of resuspendable sediment by $7.7 \%$ carbon and $0.8 \%$ nitrogen (Table 4) yields

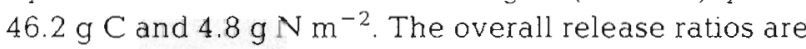
$1.23 \times 10^{-4} \mathrm{~g}$ POC $\mathrm{g}^{-1}$ sediment $(0.0123 \%)$ and $1.3 \times 10^{-5} \mathrm{~g} \mathrm{PN} \mathrm{g}^{-1}$ sediment $(0.0013 \%)$. Assuming homogeneous mixing in a $10 \mathrm{~m}$ water column, this becomes about $4.9 \mathrm{mg} \mathrm{C}$ and $0.51 \mathrm{mg} \mathrm{N} \mathrm{I}^{-1}$ (compare with Table 5). To make a similar estimate of the increase in bacterial concentration in a $10 \mathrm{~m}$ water column, the regression equation which describes resuspended bacteria as a function of resuspended nitrogen may be used [bacteria $=8464(\mathrm{~N})-3.4 \times 10^{4} ; \mathrm{r}^{2}=$ $0.292, \mathrm{p}=0.0001$, where $\mathrm{N}$ is in $\mu \mathrm{g} \mathrm{Nl}^{-1}$, bacteria are expressed as cells $\left.\mathrm{ml}^{-1}\right]$. The result is an increase in the bacterial concentration of $4.3 \times 10^{6}$ cells $\mathrm{ml}^{-1}$ (release ratio $=1.08 \times 10^{8}$ cells $\mathrm{g}^{-1}$ sediment). These estimates 
of post-storm concentrations are similar to concentrations observed during a storm in October 1987: up to $2.7 \mathrm{mg} \mathrm{Cl}^{-1}, 0.39 \mathrm{mg} \mathrm{N}^{-1}, 3 \times 10^{6}$ cells ml $^{-1}$ (Griffith et al. unpubl.).

\section{Quality vs quantity}

The quantity of any substance resuspended depends strongly on at least 3 factors: the concentration of the substance in the sediment, the erodibility of the sediment, and the shear velocity. The first 2 factors are determined by a complex interaction of physical and biological factors including grain size distribution, hydrodynamic history, organic content, and resident biota (see e.g. Eckman et al. 1981, Grant et al. 1982, Grant \& Gust 1987). Given similar sedimentation inputs, sediments which are resuspended on each tidal cycle (such as at Stn $\mathrm{MC}$ ) or as a result of frequent wave action (such as at Stn IS) migth be expected to be organically poorer than those remaining stationary for an extended period

In terms of resuspended carbon, the resuspension of large quantities of low-C material may have the same net effect as the resuspension of a small amount of organically rich, but less erodable sediment. Stn IS sediments were relatively low in organic content (Table 2); however, the resuspendable portion was comparable to or higher in organic content than that from other stations (Table 4). Assuming that resuspendable material from all stations had similar organic contents, and using data from October in the \% resuspended' column of Table $4,0.66 / 0.16=4.125$ times the sediment at Stn IS must be eroded to produce the same amount of resuspended carbon as at Stn OS. In fact, the amount of sediment eroded at $u_{\star}=1.5 \mathrm{~cm} \mathrm{~s}^{-1}$ was 6.5 times greater at Stn IS than at OS (data not shown). Thus, the opposing effects of organic content vs erodibility seemed to balance each other in this case.

Sedimentary organic matter is widely believed to be of relatively low quality, however some simple calculations suggest that this is not necessarily so. Chlorophyll content (Table 2) provides an indication of the quality of the sedimentary organic matter. Using a factor of 50:1 for converting chlorophyll a to organic $\mathrm{C}$ [this value is toward the lower range of values given in Parsons et al. (1977) and Mann (1982) for phytoplankton], $50 \mu \mathrm{g} \mathrm{C} \mathrm{g}^{-1}$ of sediment, or $5 \%$ of sedimentary organic $\mathrm{C}$ content, is attributable to phytoplankton. To this can be added organic $C$ contributed by bacteria [assuming $10^{9}$ cells $\mathrm{g}^{-1}$, mean cell volume $=0.5 \mu \mathrm{m}^{3}$, $106 \mathrm{fg} \mathrm{C} \mu \mathrm{m}^{-3}$ (Nagata 1986)] which brings the contribution of labile organic $\mathrm{C}$ to $10 \%$. This excludes protozoans (which may contribute substantially to microbial biomass; Fig. 7), other meiofauna, macrofauna, and unknown quantities of unidentified labile organic matter. Also excluded are dissolved organic $\mathrm{C}$ or dissolved inorganic nutrients released during resuspension, each of which may stimulate pelagic production (Fanning et al. 1982, Hopkinson 1987). Thus it is probable that the resuspension of sediments which contain a fully developed community may contribute significantly to pelagic pools of labile organic carbon.

\section{Particulate vs dissolved}

Resuspension apparently plays a much larger role in redistributing particulate nutrients than dissolved nutrients in this study area. Using porewater concentrations of $\mathrm{NH}_{4}^{+}, \mathrm{NO}_{3}^{-}$, and $\mathrm{PO}_{4}^{3--}$ from Hopkinson (1987: 100,20 , and $45 \mu \mathrm{M}$, respectively), assuming $100 \%$ release of those substances when $25 \mathrm{~cm}$ of sediment is fluidized, and averaging the result over a $10 \mathrm{~m}$ water column, the water column concentration would increase by ca $1.13 \mu \mathrm{M} \mathrm{NH} \mathrm{NH}_{4}^{+}, 0.23 \mu \mathrm{M} \mathrm{NO} \mathrm{NO}_{3}^{-}$, and $0.51 \mu \mathrm{M} \mathrm{PO}_{4}^{3-}$, respectively, with release ratios of $5.5 \times$ $10^{-7} \mathrm{~g} \mathrm{~N} \mathrm{~g}^{-1}$ sediment and $2.0 \times 10^{-7} \mathrm{~g} \mathrm{P} \mathrm{g}^{-1}$ sediment. These results compare with typical field concentrations of $0.5 \mu \mathrm{M} \mathrm{NH}_{4}^{+}, 0.25 \mu \mathrm{M} \mathrm{NO}_{3}^{-}$, and $0.7 \mu \mathrm{MPO}_{4}^{3-}$ (Hopkinson 1987). The percentage increase in dissolved nutrients as a result of sediments being fluidized to a depth of $25 \mathrm{~cm}$ is similar to the percentage increase in particulate substances in just a few hours at a $u_{\star}$ of 1.16 or $1.5 \mathrm{~cm} \mathrm{~s}^{-1}$ (Table 3 ).

\section{Do flume results mimic nature?}

Up to ca $u_{*}=1.2 \mathrm{~cm} \mathrm{~s}^{-1}$, the flume mimics conditions on a flat sand-bed quite well. At shear velocities greater than about $u_{*}=1.2 \mathrm{~cm} \mathrm{~s}^{-1}$ gullies began to develop at the corners of some box cores. Flux estimates at higher shear velocities may therefore overestimate resuspension on a flat sand bed, a situation which might be argued to be atypical in nature. Erosion at these higher shear velocities may more closely mimic that which might occur near a rock, sand ripple, reef edge, or biotic structures such as sea urchins and polychaete tubes (Eckman et al, 1981, Carey 1983), I have frequently observed the following roughness elements in the study area: onuphid and oweniid polychaete tubes (up to $7 \times 0.5 \mathrm{~cm}$, densities of several hundred $\mathrm{m}^{-2}$ ), sea urchins, sand dollars, large mollusc shells, rocks and sand ripples.

Annular flumes have several advantages over other flume designs for use in resuspension experiments: (1) they are recirculating in that the same water passes over the sediment core repeatedly, leading to relatively high concentrations of suspended material; (2) unlike 
straight-channel recirculating flumes, water is not passed through a water pump which might physically alter suspended particles and associated organisms, and the chemical composition of the water; (3) the boundary layer is fully developed throughout the flume, unlike in a straight channel where the boundary layer grows in a downstream direction; (4) the use of intact sediment has obvious advantages when results are to be extrapolated to nature. A disadvantage of the annular design is the secondary circulation pattern associated with the shape of the channel, which creates non-uniform shear velocities across the sediment surface, and makes calibration both difficult and laborious. The calibration problem was largely overcome by the use of flush-mounted skin friction sensors (Wainright unpubl.).

\section{CONCLUSIONS}

These results and extrapolations support Hopkinson's (1985) contention that resuspension may be a major influence on organic matter cycling in shallowwater marine environments. Resuspension can shift the major pools of particulate organic matter from the benthos to the water column. A significant part of this organic matter may be labile, and thus of immediate nutritive value to filter-feeding organisms. Previous work on this topic (Wainright 1987) showed that the longer-term impact of resuspended sediments on planktonic microbes could be very significant, even when the initial microbial contribution to the water column was indistinguishable from background. Measured fluxes in the present study exceeded those used in Wainright's (1987) study, and were themselves probably conservative estimates of field conditions during storms. Thus, the long-term stimulatory effect of resuspension fluxes on planktonic microbes should be even greater. Resuspension appears to be an important influence on the cycling of particulate carbon and nitrogen which persists much longer (days to weeks) than the resuspension event itself.

Acknowledgements. I thank the captain and crew of the RV 'Bluefin' for their able assistance in sample collection; R. Hanson, S. Bishop, J. Blanton, and J. Eckman for the use of therr facilities and equipment; R. Risley for careful attention to CHN analyses; R. Krusberg for assistance in building the shear stress sensor, and $G$. Gust for providing facilities for its calibration; F. Pearson for fabricating parts of the flume. B. Biddanda, A. DeBiase and P. Griffith assisted in sampling. Special thanks to $T$ Gross for running his version of the wavecurrent interaction model, and L. Pomeroy for his continuous support and advice throughout this project. Critical reviews by C. Hopkinson, L. Pomeroy, J. Porter, E. Sherr, S. Saupe, W Weibe and 2 anonymous reviewers greatly improved the manuscnpt. This work was supported by DOE Grant DEFGo9-86ER60451 to L. Pomeroy.

\section{LITERATURE CITED}

Bell, C. R., Albright, L. J. (1981). Attached and free-floating bacteria in the Frazer River Estuary, British Columbia, Canada. Mar. Ecol. Prog. Ser 6: 317-327

Bidigare, R. R., Kennicutt, M. C. II, Brooks, J. M. (1985). Rapid determination of chlorophylls and their degradation products by high-performance liquid chromatography. Limnol. Oceanogr. 30: 432-435

Carey, D. A. (1983). Particle resuspension in the benthic boundary layer induced by flow around polychaete tubes. Can. J. Fish. Aquat. Sci. 40 (Suppl. 1): 301-308

Eckman, J E., Nowell, A. R. M., Jumars, P. A. (1981). Sediment destabilization by animal tubes. J mar. Res. 39: 361-374

Fanning, K. A., Carder, K. L., Betzer, P. R. (1982). Sediment resuspension by coastal waters: a potential mechanism for nutrient re-cycling on the ocean's margins. Deep Sea Res. 29: 953-965

Ferguson, R. L., Davis, W. R., Draxler, A. F. J., Jacobsen, T R. (1987). Erodibility of benthic bacteria in wastewater sludge enriched coastal sediments. Eos (Abstract) 68: 1775

Fukuda, M. K., Lick. W. (1980). The entrainment of cohesive sediments in freshwater J. geophys. Res. 85 (C5): $2813-2843$

Grant, J., Gust, G. (1987). Prediction of coastal sediment stability from photopigment content of mats of purple sulphur bacteria. Nature, Lond. 330: 244-246

Grant, W. D., Boyer, L. F., Sanford, L. P. (1982). The effects of bioturbation on the initiation of motion of intertidal sands. J. mar. Res. 40: 659-677

Grant, W. D. Madsen, O. S. (1979). Combined wave and current interaction with a rough bottom. J geophys. Res. 84 (C4): 1797-1808

Gust, G. (1988). Skin friction probes for field applications. J. geophys. Res. 93 (C11): 14121-14132

Gust, G., Morris, M. J. (1989). Erosion thresholds and entrainment rates of undisturbed in situ sediments. J. Coastal Res. Special Issue 5: 87-99

Haines, E. B., Dunstan, W. M. (1975). The distribution and relation of particulate organic material and primary productivity in the Georgia Bight, 1973-1974. Estuar. coast. mar. Sci. 3: 431-441

Hedges, J. I., Stern, J. H. (1984), Carbon and nitrogen determinations of carbonate-containing solids. Limnol. Oceanogr. 29: $657-663$

Hopkinson, C. S. Jr (1985). Shallow-water benthic and pelagic metabolism: evidence of heterotrophy in the nearshore Georgia Bight. Mar. Biol. 87: 19-32

Hopkinson, C. S. Jr (1987). Nutrient regeneration in shallowwater sediments of the estuarine plume region of the nearshore Georgia Bight, USA. Mar Biol. 94: 127-142

Kirchman, D. (1983). The production of bacteria attached to particles in a freshwater pond. Limnol. Oceanogr 28 : $858-872$

Mann, K. H. (1982). Ecology of coastal waters: a systems approach. University of California Press, Berkeley

Nagata, T (1986). Carbon and nitrogen content of natural planktonic bacteria. Appl. environ. Microbiol. 52: 28-32

Nishino, S. F. (1986). Direct acridine orange counting of bacteria preserved with acidified Lugol iodine. Appl. environ. Microbiol. 52. 602-604

Nowell, A. R. M., Jumars, P. A. (1984). Flow environments of aquatic benthos. Ann. Rev. Ecol. Syst. 15: 303-328

Oertel, G. F., Dunstan, W M. (1981). Suspended-sediment distribution and certain aspects of phytoplankton production off Georgia, U.S.A. Mar. Geol. 40: 171-197

Palumbo, A. V., Fergusen, R. L., Rublee, P. A. (1984). Size of 
suspended bacterial cells and association of heterotrophic activity with size fractions of particles in estuarine and coastal waters. Appl environ. Microbiol 48: 157-164

Parsons, T. R., Takahashi, M., Hargrave, B. (1977). Biological oceanographic processes, 2nd edn. Pergamon, New York

Plummer, D. H., Owens, N. J. P., Herbert, R. A. (1987). Bacteria-particle interactions in turbid estuarne environments. Cont. Shelf Res 7 (11-12): 1429-1433

Pomeroy, L. R. (1985). The microbial food web of the southeastern U.S. continental shelf. In: Atkinson, L. P., Menzel, D. W., Bush, K. A. (eds.) Oceanography of the southeastern U.S. continental shelf. Am. Geophys. Union, Washington, D. C., p. $118-129$

Rhoads, D. C. (1973). The influence of deposit-feeding benthos on water turbidity and nutrient recycling. Am. J. Sci. 273: 1-22

Rhoads, D. C., Tenore, K., Brown, M. (1975). The role of resuspended bottom mud in nutrient cycles of shallow embayments. In: Estuarine research, Vol. 1: Chemistry, biology and the estuarine system. Academic Press, New York, p. 653-679

Rhoads, D. C., Boyer, L. F., Welsh, B. L., Hampson, G. R. (1984). Seasonal dynamics of detritus in the benthic turbidity zone (BTZ); implications for bottom-rack molluscan mariculture. Bull. mar Sci. 35 (3): 536-549

Rhoads, D. C., Yingst, J. Y., Ullman, W. J. (1978). Seafloor stability in central Long Island Sound: Part 1. Temporal changes in erodibility of fine-grained sediments. In: Wiley,

This article was presented by Dr S. Y Newell, Sapelo Island, Georgia, USA
M. L. (ed.) Estuarine interactions. Academic Press, New York, p. 221-244

Schoenberg, S. A., McCubbin, A. E. (1985). Relative feeding rates on free and particle-bound bacteria by freshwater macrozooplankton. Limnol. Oceanogr 30: 1084-1090

Tenore, K. R. (1977). Food chain pathways in detrital feeding benthic communities: a review, with niow observations on sediment resuspension and detrital recycling. In: Coull, B. C. (ed.) Ecology of marine benthos. University of South Carolina Press, Columbia, p. 37-53

Vogel, S. (1981). Life in moving fluids: the physical biology of flow. Princeton Univ. Press, Princeton, NJ

Wainright, S. C. (1985). Fluxes of particulate material and associated bacteria from sediments to the water column in the nearshore zone: laboratory estimates. Eos 66: 1315-1316 (Abstract)

Wainright, S. C. (1986). Sediment to water flux of particulate material and associated bacteria in the nearshore zone off Georgia, U.S.A.: laboratory estimates. In: Wildish, D. J. (ed.) Fluxes of particulate matter across benthic boundaries: a workshop report. Can. Tech. Rep. Fish. Aquat. Sci. 1458: $12-13$

Wainright, S. C. (1987). Stimulation of heterotrophic microplankton production by resuspended marine sediments. Science 238: 1710-1712

Wiberg, P., Smith, J. D. (1983). A comparison of field data and theoretical models for wave-current interactions at the bed on the continental shelf. Cont. Shelf Res. 2: 147-162

Manuscript first received: December 16, 1988

Revised version accepted: January 24, 1990 